\title{
Sports and hybrids of triploid Hosta 'Sum and Substance' reveal chromosome losses and gains in all three apical layers
}

\author{
B. J. M. Zonneveld • W. I. Pollock
}

Received: 13 October 2011/Accepted: 13 February 2012/Published online: 6 March 2012

(C) The Author(s) 2012. This article is published with open access at Springerlink.com

\begin{abstract}
Ploidy distributions in L1, L2, and L3 apical or meristematic layers of 56 different plants (79 accessions) from vegetative and sexual progeny of the triploid Hosta 'Sum and Substance' were determined. Nuclear DNA contents $(2 C)$ of each apical layer were measured by flow cytometry with propidium iodide, and inferred ploidies are calculated. During tissue culture, the triploid (L1-L2L3 = 3-3-3) Hosta 'Sum and Substance' exhibited chromosome losses resulting in somaclonal variants such as DNA aneuploids (e.g., 2.7-2.7-2.7) and aneuploidy chimeras (e.g., 3-2.7-2.7). Most interestingly, some chimeras exhibited even an increase in genome size as in plants with 3.5-3-3 configuration. Hybrids of $H$. 'Sum and Substance' show only losses of nuclear DNA compared with the original triploid. This gives rise to fully aneuploid plants and no chimeras. The measurements of Hosta 'Sum and Substance' lineages of sports and hybrids indicate that chromosome losses or gains are an important source of new cultivars. The complexity of chromosomal distribution in derivatives from the triploid Hosta 'Sum and Substance' is discussed.
\end{abstract}

Keywords Somaclonal variants - Chromosome losses and gains - Sports and hybrids - Triploid Hosta 'Sum and Substance'

B. J. M. Zonneveld ( $\square$ )

Herbarium Section, NCB Naturalis, PO Box 9514,

2300RA Leiden, The Netherlands

e-mail: Zonneveld@NHN.Leidenuniv.nl

W. I. Pollock

Glen Mills, PA, USA

e-mail: giboshiwip@aol.com

\section{Introduction}

Hosta is a herbaceous perennial found in Japan, Korea, China, and southeastern Russia. They are the best-selling perennial in the USA and popular in Europe and Japan, and therefore of considerable economic importance.

Most dicotyledons and monocotyledons are basically built from three apical or meristematic layers named L1, L2, and L3 (Stewart and Dermen 1979; Lineberger 2000; Zonneveld 2007). Contrary to dicotyledons, in monocotyledons L1 contains chloroplasts and forms, sometimes extensively, the margin of the leaf. A hosta leaf consists of about nine cell layers. The three apical layers in the leaf are concentric, with two cell layers for the outer L1, two cell layers for the subepidermal L2, and four to five cell layers for the core L3 (Zonneveld 2007). The actual presence in Hosta of three apical layers in all organs but not the adventitious roots was demonstrated previously (Zonneveld 2007). All Hosta species are diploid (2-2-2) with $2 x=60$, except $H$. clausa var. clausa, which is triploid (3-3-3), and H. ventricosa, which is allotetraploid (4-4-4) (Kaneko 1968; Zonneveld and Van Iren 2001). Changes in chromosome number can occur during growth or sexual propagation. Complete chromosome doubling results in polyploids (for example, 2-2-2 $\rightarrow$ 4-4-4); incomplete chromosome doubling results in ploidy chimeras (2-2$2 \rightarrow 4-2-2$ ). Ploidy chimeras, also designated cytochimeras and genetic mosaics, have different ploidies in at least one of the three genetic layers (Marcotrigiano 1997, 2001). Characteristically, ploidy chimeras and polyploid hostas have similar phenotypical traits. Compared with diploids, often leaves are thicker and broader and plants have shorter petioles and more upright foliage, and are slower growing. Also, differently colored leaf margins are significantly wider with brighter coloring. This is similar to what was 
found for ploidy chimeras of Azalea (De Schepper et al. 2001). Flowers of fully tetraploid hostas customarily are slightly larger and frequently more upright facing than partially tetraploid hostas.

The advantage of ploidy chimeras is that they can be followed in all tissues. This is in contrast to chloroplast chimeras that moreover require extensive histological analysis (Satina et al. 1940). Flow cytometry is a very convenient methodology for analysis of plant lineages, provided ploidy chimeras are available. In general, flow cytometry can only reveal differences in genome sizes of over $2 \%$. As a consequence low levels of aneuploidy could not be excluded (Roux et al. 2003). However, it can be used to screen many plants in a short time, can be applied to any plant tissue, and gives information on all three apical layers. This is contrary to the time- and labor-consuming coloring of metaphase chromosomes for only root tips (representing L3) that are usually used for analysis.

DNA aneuploidy in Hosta was initially discovered in $H$. 'Stitch in Time' having an inferred ploidy of L1-L2$\mathrm{L} 3=4-2.5-3.6$, a tissue-cultured sport from a tetraploid parent (Zonneveld et al. 2009). In a recent study, several other inferred aneuploids and aneuploidy chimeras in Hosta cultivars were found (Zonneveld and Pollock 2012, in press).

In this study 54 different sports, hybrids, and openpollinated seedlings of Hosta 'Sum and Substance' were investigated. The amount of DNA per nucleus (nuclear DNA content or $2 C$ value) was measured by flow cytometry with propidium iodide. Ploidies are inferred from comparison with the nuclear DNA content of the parent cultivar, the triploid $H$. 'Sum and Substance' with nuclear DNA content $(2 C)$ of $36.3 \mathrm{pg}$. This has been shown in Musa to agree with chromosome counts (Roux et al. 2003). Diploid Hosta species vary in nuclear DNA content from 17 to $26 \mathrm{pg}$ (Zonneveld and Van Iren 2001), resulting in a range for triploids from 25.5 to $39 \mathrm{pg}$. Previously inferred ploidies in a random mix of aberrant hostas were investigated (Zonneveld and Van Iren 2000; Zonneveld 2007; Chamberlain 2008; Zonneveld et al. 2009; Chamberlain et al. 2011; Zonneveld and Pollock 2012, in press). This study specifically investigated ploidy distributions in L1, L2, and L3 layers of somaclonal variants and hybrids of one of the largest hostas: triploid $H$. 'Sum and Substance'. We determined whether sports and hybrids of 'Sum and Substance' are triploids like 'Sum and Substance' or have chromosome losses or gains, and therefore are new important sources of Hosta cultivars. A recent study (Zonneveld and Pollock 2012, in press) revealed aneuploids and aneuploidy chimeras in somaclones of diploid Hosta cultivars.

\section{Materials and methods}

Plant material

Hostas were obtained from the collections of Thomas S. Carlson, HostasDirect, Roseville, Minnesota; Steven C. Chamberlain, Manlius, New York; C.H. Falstad III, Walters Gardens, Zeeland, Michigan; Marco Fransen, Fransen Hostas, Ter Aar, The Netherlands; James Schwarz, Jim's Hostas, Dubuque, Iowa; Robert M. Solberg, Green Hill Farm, Franklinton, North Carolina; Mark R. Zilis, Q and Z Nursery, Rochelle, Illinois; and B.J.M. Zonneveld, NCB Naturalis, Herbarium Section, Leiden, The Netherlands. Care was taken to ensure correct identification of all material.

Flow cytometric measurement of DNA $2 C$ value

For isolation of nuclei, about $1 \mathrm{~cm}$ of leaf or a few $\mathrm{cm}$ of root was chopped together with a piece of Agave americana L. 'Aureomarginata' as an internal standard. Chopping was done with a new razor blade in a Petri dish in $0.25 \mathrm{ml}$ nuclei-isolation buffer (Galbraith et al. 1983) to which $0.25 \mathrm{mg}$ RNase/ml was added (Zonneveld and Van Iren 2001). After adding $1.75 \mathrm{ml}$ propidium iodide solution (50 mg PI/l in isolation buffer), the suspension with nuclei was filtered through a $30-\mu \mathrm{m}$ nylon filter. The fluorescence of the nuclei was measured $0.5 \mathrm{~h}$ and $1 \mathrm{~h}$ after addition of propidium iodide, using a Partec CA-II flow cytometer. The optical path contained a HBO mercury lamp, filters KG1, BG12, dichroic mirror TK500, filter OG570, and a Leitz $50 \times 1$ water immersion objective. Data were analyzed by means of DPAC software (Partec $\mathrm{GmbH})$. Fresh male human leukocytes $\left(2 C=7.0 \mathrm{pg} ; 1 \mathrm{pg}=10^{-12} \mathrm{~g}=\right.$ $0.978 \times 10^{9}$ base pairs) (Doležel et al. 2003) were chosen as primary standard (Tiersch et al. 1989). This yields $2 C=15.9 \mathrm{pg}$ for nuclei of Agave americana $\mathrm{L}$. The $2 C$ DNA content of the sample was calculated as the sample peak mean, divided by the Agave peak mean, and multiplied with the amount of DNA of the Agave standard. Most samples were measured at least four times, each time with about 5,000 nuclei. Most histograms revealed a coefficient of variation of around 5\%. The standard deviation for nuclear DNA content, using all relevant measurements, was about $2 \%$.

Separate measurement of the three apical layers

To investigate the amount of nuclear DNA of cells of each apical layer, first a small piece of the center of the leaf was investigated. This covers all three apical layers L1, L2, and L3. A single peak in the histogram will appear if all three 
layers have the same amount of nuclear DNA. If there are two peaks, the highest of the peaks is L3 and the lower one is L1 or L2. This is because L1 and L2 each consist of two cell layers while L3 consists of five cell layers. If there is more than one peak, L1 and L3 are investigated separately. $\mathrm{L} 1$, forming the edge of the leaf, is easily recognized, especially in cultivars with a different colored edge. L3 is determined from the roots that are all adventitious in Hosta. For hostas it is found that about $25 \%$ of the root nuclei show endopolyploidy (Zonneveld and Van Iren 2000). Combining these results, one can determine the amount of DNA in each of the three layers. Inferred ploidy (=DNA ploidy, Suda et al. 2006) is then calculated in comparison with the nuclear DNA content and the ploidy of the parent cultivar.

\section{Results and discussion}

Tissue cultures of Hosta are started with an excised shoot tip and not multiplied via callus but via adventitious buds. After growing for a while in a greenhouse, those plants that show a commercially interesting deviation are selected. Sometimes circumstances in tissue culture are unnatural with high amounts or unbalanced concentrations of growth hormones. This might lead to a change in methylation patterns and chromosome breakage (Phillips et al. 1994). However, in general, the chromosomal order of the three layers is not easily disturbed in tissue-culture propagation of Hosta. This is shown by the tens of thousands of tissuecultured periclinal chimeras identical to the original explants. Tables 1, 2, and 3 list the data on sports (vegetative progeny) and hybrids of 'Sum and Substance', inferred ploidy in the L1-L2-L3 layers, amount of nuclear DNA ( $2 C$ value in picograms) measured for L1, L2, and L3 layers, and nursery source. Some hosta cultivars are grouped by lineage, such as first-generation sports and subsequent sports.

\section{Hosta 'Sum and Substance'}

Hosta 'Sum and Substance' is a popular cultivar with huge yellow-green leaves; clump height is often more than $1 \mathrm{~m}$ and width $2 \mathrm{~m}$. 'Sum and Substance' is a hybrid, parentage unknown, registered with The American Hosta Society by Paul Aden in 1980. A possible origin of 'Sum and Substance' is as a seedling of the green Hosta montana f. macrophylla or Hosta 'Elatior' (as a nonreduced gamete) and a yellow sport of Hosta sieboldiana. This is in accordance with the size and the yellow-green color of 'Sum and Substance'. There are at least 50 named sports and 30 named hybrids of 'Sum and Substance' from many breeding programs and open pollination. Of these, 56 are investigated here. In a previous study, 'Sum and Substance' was determined to have nuclear DNA content of $36.3 \mathrm{pg}$, congruent with it being triploid (3-3-3) (Chamberlain et al. 2011). This was confirmed by two new samples of 'Sum and Substance', from difference sources (Table 1).

\section{Hosta 'Sum and Substance' sports}

A (bud) sport is a shoot deviating from the parent plant. In Hosta it is mostly observed as a change in chloroplast pattern of the leaf. This change is often due to a chimeral rearrangement of the layers in the apical meristem (in a variegated plant) or to a somatic crossing-over between chromosomes in the apical meristem (in a heterozygous plant). It is rarely due to a mutation (best seen in a green plant). However, involvement of chromosome instability, unstable transposable elements, or epigenetic changes cannot be excluded, especially in sports that show a spotted phenotype. Table 1 gives data for 28 sports of 'Sum and Substance' divided into five groups. The first group lists first-generation sports of 'Sum and Substance' where there is no concomitant change in the nuclear amount of DNA. They are all triploid with $2 C$ value similar to 'Sum and Substance'. They were principally selected as having leaf coloring different from 'Sum and Substance'.

The second group also is first-generation sports of 'Sum and Substance'. However, nuclear DNA contents (2C) and the inferred ploidies indicate that they are aneuploids and aneuploidy chimeras that mostly lost DNA. The exception is $H$. 'Eagle's Nest', an amazing hypertetraploid that gained DNA in L3 with L1-L2-L3 = 3-3-4.3. Such losses and gains might be due to the triploidy of 'Sum and Substance', aggravated by unnatural circumstances in tissue culture, leading to unbalanced mitoses (De Schepper et al. 2001).

Two accessions of $H$. 'Sum Cup-o-Joe' (\#1 and \#2) were plain triploid. However, the third one (\#3) lost chromosomes and now has L1-L2-L3 $=2.8-2.8-2.8$. This indicates that chromosome loss as such is not always recognizable in a cultivar's phenotypic characteristics.

Exceptional also is the appropriately named $H$. 'Sum of All'. It shows a different inferred ploidy in each of the three layers L1, L2, and L3 with 3-2.7-2.5. Further unusual is $H$. 'Titanic' with $\mathrm{L} 1-\mathrm{L} 2-\mathrm{L} 3=3-2.8-2.8$. Two layers are aneuploid, a result not found earlier in 124 other Hosta cultivars (Zonneveld and Pollock 2012, in press).

Three groups then follow with lineages of sports. $H$. 'Final Summation' is first generation of 'Sum and Substance'. It has golden-yellow leaves with a wide darkgreen margin. It gave rise to $H$. 'Zero Sum' with plain dark-green leaves. Both are aneuploid and have only slight DNA loss, with an inferred ploidy of 2.9 instead of 3 in each of the three layers. 
Table 1 Genome size and inferred ploidy of Hosta 'Sum and Substance' sports

\begin{tabular}{|c|c|c|c|c|}
\hline Hosta cultivar & Sport of & Inferred ploidy, L1-L2-L3 & DNA $(2 C)$ in $p g, \mathrm{~L} 1-\mathrm{L} 2-\mathrm{L} 3$ & Source \\
\hline 'Sum and Substance' \#1 & (Hybrid) & $3-3-3$ & $36.4-36.4-36.4$ & (Previous studies) \\
\hline 'Sum and Substance' \#2 & (Hybrid) & $3-3-3$ & $36.3-36.3-36.3$ & Jim's Hostas \\
\hline 'Sum and Substance' \#3 & (Hybrid) & $3-3-3$ & $36.3-36.3-36.3$ & Fransen Hostas \\
\hline 'Bottom Line' & $S \& S$ & $3-3-3$ & $36.3-36.3-35.7$ & HostasDirect \\
\hline 'Blizzard' & $S \& S$ & $3-3-3$ & $36.1-36.1-36.1$ & Jim's Hostas \\
\hline 'Corona' & $S \& S$ & $3-3-3$ & $37.2-37.2-37.2$ & Jim's Hostas \\
\hline 'David A. Haskell' & S\&S & $3-3-3$ & $36.2-36.2-36.2$ & Jim's Hostas \\
\hline 'Domaine de Courson' & $S \& S$ & $3-3-3$ & $36.3-36.3-36.3$ & Fransen Hostas \\
\hline ‘Fran Godfrey’ \#1 & S\&S & $3-3-3$ & $36.5-36.5-36.5$ & Jim's Hostas \\
\hline 'Fran Godfrey' \#2 & $S \& S$ & $3-3-3$ & $36.6-37.0-37.0$ & Fransen Hostas \\
\hline 'Gunther's Prize' & S\&S & $3-3-3$ & $36.3-36.3-36.3$ & Jim's Hostas \\
\hline 'Lady Isabel Barnett' & S\&S & $3-3-3$ & $35.6-35.6-35.6$ & HostasDirect \\
\hline 'Parhelion’ & S\&S & $3-3-3$ & $35.9-35.9-35.5$ & HostasDirect \\
\hline 'Prairie Sum Shine’ \#1 & S\&S & $3-3-3$ & $36.5-36.5-36.5$ & Jim's Hostas \\
\hline 'Prairie Sum Shine' \#2 & S\&S & $3-3-3$ & $36.3-36.3-36.3$ & Fransen Hostas \\
\hline 'Sum and Subtle' & $\mathrm{S} \& \mathrm{~S}$ & $3-3-3$ & $36.1-36.1-36.1$ & Fransen Hostas \\
\hline ‘Sum Cup-o-Joe’ \#1 & S\&S & $3-3-3$ & $36.4-36.4-36.4$ & Fransen Hostas \\
\hline 'Sum Cup-o-Joe' \#2 & S\&S & $3-3-3$ & $36.2-36.2-36.2$ & Fransen Hostas \\
\hline 'Tiffney Gonzilla' & S\&S & $3-3-3$ & $36.1-36.1-36.1$ & Jim's Hostas \\
\hline ‘Winter Snow’ \#1 & S\&S & $3-3-3$ & $36.2-36.2-36.2$ & Jim's Hostas \\
\hline ‘Winter Snow’ \#2 & S\&S & $3-3-3$ & $36.1-35.6-35.6$ & Fransen Hostas \\
\hline 'Zebson’' & $S \& S$ & $3-3-3$ & $36.9-36.9-36.9$ & Jim's Hostas \\
\hline 'Eagle's Nest' & S\&S & $3-3-4.3$ & $36.2-36.2-51.9$ & (Previous studies) \\
\hline 'Something Good' & S\&S & $3-2.7-2.7$ & $36.6-32.3-32.3$ & Jim's Hostas \\
\hline ‘Sum Cup-o-Joe’ \#3 & S\&S & $2.8-2.8-2.8$ & $34.0-34.0-34.0$ & Fransen Hostas \\
\hline ‘Sum of All’ & S\&S & $3-2.7-2.5$ & $36.4-32.5-30.4$ & HostasDirect \\
\hline ‘Titanic’ PP \#1 & S\&S & $3-2.8-2.8$ & $36.2-33.4-33.4$ & (Previous studies) \\
\hline ‘Titanic' PP \#2 & $\mathrm{S} \& S$ & $3-2.8-2.8$ & $36.6-33.7-33.7$ & HostasDirect \\
\hline ‘Titanic’ PP \#3 & $\mathrm{S} \& S$ & $3-2.8-2.8$ & $36.6-33.7-33.7$ & Fransen Hostas \\
\hline 'Vim and Vigor' & $\mathrm{S} \& \mathrm{~S}$ & $2.8-2.8-2.8$ & $34.0-34.0-34.3$ & Walters Gardens \\
\hline 'Final Summation' \#1 & S\&S & $2.9-2.9-2.9$ & $35.7-36.2-35.3$ & Green Hill Farm \\
\hline ‘Final Summation’ \#2 & $\mathrm{S} \& \mathrm{~S}$ & $2.9-2.9-2.9$ & $35.4-35.4-35.4$ & Fransen Hostas \\
\hline ‘Zero Sum’ \#1 & 'Final Summation' & $2.9-2.9-2.9$ & $35.4-35.4-35.4$ & Green Hill Farm \\
\hline 'Zero Sum’ \#2 & 'Final Summation’ & $2.9-2.9-2.9$ & $35.0-35.0-35.0$ & Fransen Hostas \\
\hline ‘Lodestar’ \#1 & S\&S & $2.7-2.7-2.7$ & $32.6-32.6-32.6$ & Jim's Hostas \\
\hline 'Lodestar' \#2 & $\mathrm{S} \& \mathrm{~S}$ & $2.7-2.7-2.7$ & $31.8-31.8-31.8$ & Jim's Hostas \\
\hline 'Follow Your Dream' \#1 & 'Lodestar' & $2.9-2.9-2.9$ & $36.0-36.0-36.0$ & Jim's Hostas \\
\hline 'Follow Your Dream' \#2 & 'Lodestar' & $2.9-2.9-2.9$ & $35.0-35.0-35.0$ & Jim's Hostas \\
\hline ‘True North’ \#1 & 'Lodestar' & $2.9-2.9-2.9$ & $35.5-35.5-35.5$ & Jim's Hostas \\
\hline ‘True North’ \#2 & 'Lodestar' & $2.9-2.9-2.9$ & $35.0-35.0-35.0$ & Jim's Hostas \\
\hline 'Sum It Up’ & $\mathrm{S} \& S$ & $3-3-3$ & $36.1-36.1-35.5$ & HostasDirect \\
\hline 'Friar Tuck' & 'Sum It Up’ & $3.5-3-3$ & $42.7-36.2-36.2$ & Jim's Hostas \\
\hline ‘Buster’ \#1 & 'Friar Tuck' & $3.4-3.4-3.4$ & $41.6-41.6-41.6$ & $\mathrm{Q}$ and $\mathrm{Z}$ Nursery \\
\hline ‘Buster' \#2 & 'Friar Tuck' & $3.5-3.5-3.5$ & $43.3-43.3-43.3$ & Fransen Hostas \\
\hline
\end{tabular}


Table 2 Genome size and inferred ploidy of Hosta 'Sum and Substance': crosses with species

\begin{tabular}{|c|c|c|c|c|}
\hline Hosta cultivar & Parentage & $\begin{array}{l}\text { Inferred ploidy, } \\
\text { L1-L2-L3 }\end{array}$ & $\begin{array}{l}\text { DNA }(2 C) \text { in } p g, \\
\text { L1-L2-L3 }\end{array}$ & Source \\
\hline ‘Jaz’ \#1 & $\mathrm{S} \& \mathrm{~S} \times H$. yingeri & $2.4-2.4-2.4$ & 29.4-29.4-29.4 & Jim's Hostas \\
\hline 'Jaz' \#2 & $\mathrm{S} \& \mathrm{~S} \times H$. yingeri & $2.4-2.4-2.4$ & 28.6-28.6-28.6 & Jim's Hostas \\
\hline ‘Nancy Gill’ \#1 & $\mathrm{S} \& \mathrm{~S} \times H$. pycnophylla & $2.7-2.7-2.7$ & $32.9-32.9-32.9$ & Jim's Hostas \\
\hline ‘Nancy Gill' \#2 & $\mathrm{S} \& \mathrm{~S} \times H$. pycnophylla & $2.8-2.8-2.8$ & $33.7-33.7-33.7$ & Jim's Hostas \\
\hline 'Raleigh Remembrance' \#1 & $\mathrm{S} \& \mathrm{~S} \times H$. plantaginea & $2.5-2.5-2.5$ & $30.4-30.4-30.4$ & Jim's Hostas \\
\hline 'Raleigh Remembrance' \#2 & $\mathrm{S} \& \mathrm{~S} \times H$. plantaginea & $2.5-2.5-2.5$ & $29.6-29.6-29.6$ & Jim's Hostas \\
\hline 'Tossed Salad' \#1 & $\mathrm{S} \& \mathrm{~S} \times H$. pycnophylla & $2.3-2.3-2.3$ & $28.1-28.1-28.1$ & Jim's Hostas \\
\hline 'Tossed Salad' \#2 & $\mathrm{S} \& \mathrm{~S} \times H$. pycnophylla & $2.3-2.3-2.3$ & $27.7-27.7-27.7$ & Jim's Hostas \\
\hline
\end{tabular}

Table 3 Genome size and inferred ploidy of Hosta 'Sum and Substance' progeny: crosses with cultivars and open pollination

\begin{tabular}{|c|c|c|c|c|}
\hline Hosta cultivar & Parentage & $\begin{array}{l}\text { Inferred ploidy, } \\
\text { L1-L2-L3 }\end{array}$ & $\begin{array}{l}\text { DNA }(2 C) \text { in pg, } \\
\text { L1-L2-L3 }\end{array}$ & Source \\
\hline 'Academy Ametrine’ & Open pollinated & Aneuploid & $32.9-32.9-32.9$ & SC Chamberlain \\
\hline 'Bubba' \#1 & Open pollinated & Aneuploid & $27.3-27.3-27.3$ & (Previous studies) \\
\hline 'Bubba' \#2 & Open pollinated & Aneuploid & $27.9-27.9-27.9$ & Jim's Hostas \\
\hline 'Bubba' \#3 & Open pollinated & Aneuploid & $27.5-27.5-27.5$ & Jim's Hostas \\
\hline 'Fragrant Gold' \#1 & Open pollinated & Aneuploid & $24.7-24.7-24.7$ & Jim's Hostas \\
\hline 'Fragrant Gold' \#2 & Open pollinated & Aneuploid & $24.3-24.3-24.3$ & Jim's Hostas \\
\hline ‘Jim Cooper’ \#1 & Open pollinated & Aneuploid & $24.5-24.5-24.5$ & Jim's Hostas \\
\hline 'Jim Cooper' \#2 & Open pollinated & Aneuploid & $25.0-25.0-25.0$ & Jim's Hostas \\
\hline 'Joyce Trott' & Open pollinated & Aneuploid & $23.8-23.8-23.8$ & Jim's Hostas \\
\hline 'Metallic Sheen' & $\mathrm{S} \& \mathrm{~S} \times H$. 'Elegans' & Aneuploid & $24.3-24.3-24.3$ & Jim's Hostas \\
\hline 'Lovely Loretta' & $\mathrm{S} \& \mathrm{~S} \times H$. 'Ginko Craig' & Aneuploid & $29.3-29.3-29.3$ & Jim's Hostas \\
\hline 'M. Owen Papuga' & Open pollinated & Aneuploid & $28.5-28.5-28.5$ & SC Chamberlain \\
\hline 'Rosedale Genevieve' \#1 & H. 'Galaxy' $\times \mathrm{S} \& \mathrm{~S}$ & Aneuploid & $24.3-24.3-24.3$ & Jim's Hostas \\
\hline 'Rosedale Genevieve' \#2 & H. 'Galaxy' $\times \mathrm{S} \& \mathrm{~S}$ & Aneuploid & 29.7-29.7-29.7 & Jim's Hostas \\
\hline 'New Wave' & $\mathrm{S} \& \mathrm{~S} \times \mathrm{H}$. venusta seedling & Aneuploid & 26.9-26.9-26.9 & Jim's Hostas \\
\hline 'Leather Sheen' & $\mathrm{S} \& \mathrm{~S} \times \mathrm{H}$. venusta seedling & Aneuploid & $30.8-30.8-30.8$ & Jim's Hostas \\
\hline 'Small Sum' & Open pollinated & Aneuploid & $29.8-29.8-29.8$ & Jim's Hostas \\
\hline BZ1001 & Open pollinated & Aneuploid & $30.8-30.8-30.8$ & BJM Zonneveld \\
\hline BZ1002 & Open pollinated & Aneuploid & $32.2-32.2-32.2$ & BJM Zonneveld \\
\hline BZ1003 & Open pollinated & Aneuploid & $31.1-31.1-31.1$ & BJM Zonneveld \\
\hline BZ1004-1 & Open pollinated & Aneuploid & 28.8-28.9-28.9 & BJM Zonneveld \\
\hline BZ1004-2 & Open pollinated & Aneuploid & $33.5-33.5-33.5$ & BJM Zonneveld \\
\hline BZ1004-3 & Open pollinated & Aneuploid & $30.6-30.6-30.6$ & BJM Zonneveld \\
\hline BZ1004-5 & Open pollinated & Aneuploid & 29.7-29.7-29.7 & BJM Zonneveld \\
\hline BZ1004-6 & Open pollinated & Aneuploid & $33.8-33.8-33.8$ & BJM Zonneveld \\
\hline BZ1004-7 & Open pollinated & Aneuploid & 29.9-29.9-29.9 & BJM Zonneveld \\
\hline BZ1004-8 & Open pollinated & Aneuploid & 28.9-28.9-28.9 & BJM Zonneveld \\
\hline
\end{tabular}

The next group has $H$. 'Lodestar' as first generation. $H$. 'True North' is a sport of $H$. 'Lodestar' and a secondgeneration sport of 'Sum and Substance'. H. 'Follow Your Dream' is also a sport of $H$. 'Lodestar' and also a secondgeneration sport of 'Sum and Substance'. All three sports are aneuploid with $H$. 'Lodestar' having inferred ploidy of
2.7 and $H$. 'Follow Your Dream' and $H$. 'True North' having inferred ploidy of 2.9. This is peculiar as it shows an increase in the amount of DNA from a ploidy of 2.7 to 2.9. In the last group 'Sum and Substance' gave rise to $H$. 'Sum it Up' followed by $H$. 'Friar Tuck', which in turn is followed by $H$. 'Buster'. All three sports are different. 


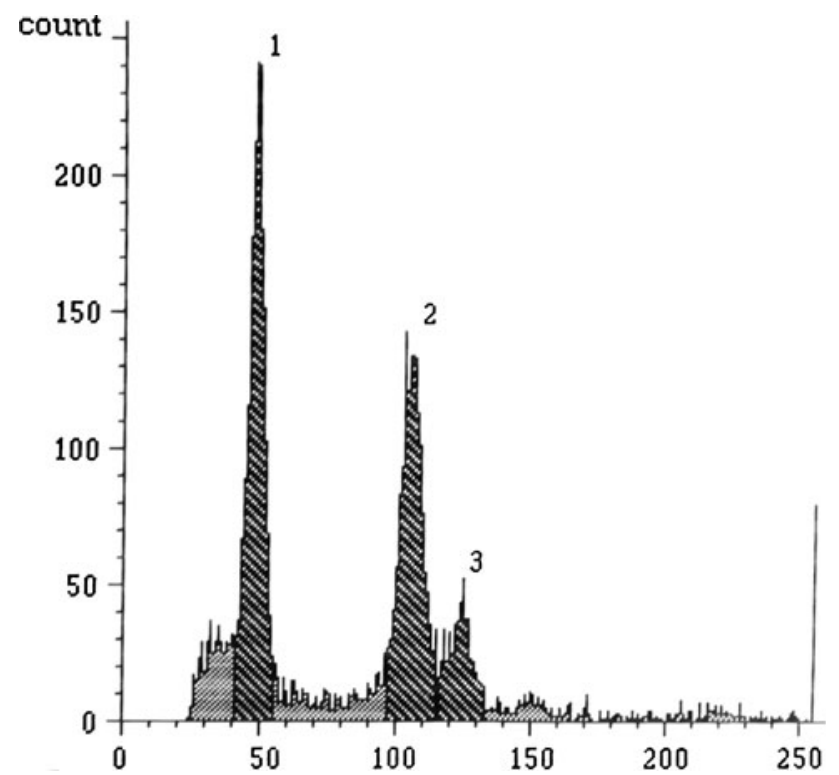

Fig. 1 Histogram of fluorescence intensity of nuclei from tissue of the center of the leaf of the chimeric aneuploid Hosta 'Friar Tuck' (ploidy is 3.5-3-3), derived from the triploid $H$. 'Sum It Up' (3-3-3). Total count was 5,092. 1. Agave americana (standard) 2. Layer $\mathrm{L} 2+\mathrm{L} 3$ of $H$. 'Friar Tuck' 3. Layer L1 of $H$. 'Friar Tuck'. The contribution of each layer was confirmed by measurements of the nuclei of the roots (=L3) and the leaf edge (=L1) (not shown)

H. 'Sum it Up' is triploid like 'Sum and Substance', $H$. 'Friar Tuck' is an aneuploid chimera with L1-L2$\mathrm{L} 3=3.5-3-3$ (Fig. 1), and $H$. 'Buster' is an aneuploid but with an inferred ploidy of 3.4 (3.5). $H$. 'Friar Tuck', with only $\mathrm{L} 1=3.5$, acquired the equivalent of half a chromosome set in sporting from 'Sum and Substance', going from triploid $(\mathrm{L} 1=3)$ to $\mathrm{L} 1=3.5$. And in $H$. 'Buster' all three layers now have the extra half of a chromosome set sporting from $H$. 'Friar Tuck' to 3.5-3.5-3.5. This increase in total genome size could be due to an unequal partitioning of chromosomes during mitosis or to an increase with a full chromosome set to hexaploidy, followed by a loss of DNA. All three layers of $H$. 'Buster' seem derived from L1 of $H$. 'Friar Tuck'.

Sometimes aneuploid and aneuploidy chimera have unusual phenotypic characteristics; For example, $H$. 'Eagle's Nest' with the highest hypertetraploid L3 has cupped and puckered leaves with heavy substance. Leaves are green with wide golden-yellow margins, having short and thick petioles and less than half the size of 'Sum and Substance' leaves. In addition, the flowering habit is unusual: tight cluster of blooms on short scapes. H. 'Lodestar', the lowest hypotriploid sport with inferred ploidy of 2.7, has some characteristics similar to 'Eagle's Nest'. Its wavy green leaves with wide gold margins are smaller than 'Sum and Substance' leaves.
H. 'Sum and Substance' progeny: crosses with Hosta species

Table 2 gives data for eight accessions that are hybrids of species crossed with $H$. 'Sum and Substance'. All have 'Sum and Substance' as pod parent.

These hybrids of 'Sum and Substance' often resemble the pollen parent. This can be explained by the fact that all Hosta species are smaller than 'Sum and Substance' and so are its hybrids. For hybrids crossed with species, the contribution of 'Sum and Substance' to the hybrid can be calculated. The amount of nuclear DNA (2C) for $H$. yingeri, $H$. pycnophylla, and $H$. plantaginea is $19.1,22.2$, and $24.7 \mathrm{pg}$, respectively (Zonneveld and Van Iren 2001). If it is assumed that the three genomes of 'Sum and Substance' are more or less equal in size, then each set would be $12.1 \mathrm{pg}$. Consequently, DNA contribution of 'Sum and Substance' in the hybrids varies from 16.6 in $H$. 'Tossed Salad' to $22.6 \mathrm{pg}$ in $H$. 'Nancy Gill', both crosses with the same species, H. pycnophylla. This falls between the DNA amount for a single (12.1 pg) and a double genome (24.2 pg) of 'Sum and Substance'. This does not mean, however, that actually whole genomes are involved; it could be any mix of chromosomes. The contribution of 'Sum and Substance' in these cases seems independent of the pollen species involved. Moreover, both hybrids are medium size and have blue-green to green leaves that are broadly ovate. Therefore the different contributions of 'Sum and Substance' in both plants are not reflected in the size or color of the plants. Gametes of a triploid plant are expected mainly to have anything between a single genome and a triploid genome, including aneuploid numbers. This will result in aneuploid hybrids. Originating from a single fertilized egg, all three layers in a seedling (hybrid) are identical, hence none is a chimera.

\section{$H$. 'Sum and Substance' progeny: crosses with cultivars} and open pollination

Table 3 lists data for 26 hybrids of $H$. 'Sum and Substance' that are mainly open-pollinated seedlings. Crosses of 'Sum and Substance' from open pollination show, in all investigated cases, loss of DNA compared with the mother plant. This is likely due to the haploidy of the gametes of the other parent. Ploidy from seedlings cannot be calculated when the pollen parent is unknown. Sports of 'Sum and Substance' can be compared with ploidy of the original (triploid) parent. However, for seedlings of 'Sum and Substance', the contribution of 'Sum and Substance', being triploid, to the seedlings is unknown. Therefore when the other parent is unknown too (i.e., is not a known species) there is no frame of reference to calculate the ploidy of the seedling. As initially stated, gametes of 'Sum and Substance' will mainly 
contribute an amount of DNA between 1 and 3 genomes. Hence, all hybrids in Table 3 are likely aneuploid as they vary in nuclear DNA content from 23.8 to $33.8 \mathrm{pg}$. This is less than the nuclear DNA content of $36.3 \mathrm{pg}$ of 'Sum and Substance' alone; thus nonreduced gametes are not involved. Remarkable is $H$. 'Metallic Sheen' that has only $24.3 \mathrm{pg}$. One of the parents is $H$. 'Elegans', reportedly a sport of $H$. sieboldiana with $23.9 \mathrm{pg}$. If we suppose that $H$. sieboldiana contributes half of its DNA (11.95 pg), the contribution of 'Sum and Substance' would be 24.3 minus $11.95=12.35 \mathrm{pg}$, close to the amount of a single genome. On the other hand, Hosta BZ1004-6 with 33.8 pg likely contains nearly two genomes of 'Sum and Substance'. Most of the chromosomes that stayed unpaired in the triploid 'Sum and Substance' during gamete formation were probably lost. Alternatively the proposed parents of 'Sum and Substance', $H$. montana and $H$. sieboldiana, could belong to the same Hosta species (Zonneveld and Van Iren 2001) and therefore their chromosomes will pair. Consequently, it cannot be excluded that trivalents (three meiotically paired chromosomes) are formed that upset the partition of chromosomes during gamete formation in 'Sum and Substance'.

\section{Conclusions}

Crosses of $H$. 'Sum and Substance' with Hosta species, other cultivars, and open pollination result in loss of DNA, implying chromosome losses, compared with the original triploid. Arising from a single fertilized egg, these hybrids are only fully aneuploid and do not result in any chimeras.

Some aneuploid sports of 'Sum and Substance' exhibit an increase in genome size compared with the triploid value of 'Sum and Substance'. This shows that also during mitosis unequal partitioning plays a critical role. This increase is not found in any of the hybrids of 'Sum and Substance', which is likely due to the haploidy of the gametes of the other parent. Sports of 'Sum and Substance' arising in tissue culture might seem to indicate abundant gains and losses, but undoubtedly aberrant forms were selectively named as cultivars among thousands of normal progeny. For interesting new somaclonal variants of 'Sum and Substance', it would seem best to use a cultivar such as $H$. 'Buster' (3.4-3.4-3.4) that has an increased amount of nuclear DNA in L2. Also tissue-culture propagation of $H$. 'Eagle's Nest' (3-3-4.3) could even result in a tetraploid 'Sum and Substance'.

Hosta 'Sum and Substance' lineages of sports and hybrids show that chromosome losses during sexual propagation and losses or gains during asexual propagation are an important source of new cultivars.

Acknowledgments The authors thank the persons mentioned under "Materials and methods" for providing most of the hostas.
Open Access This article is distributed under the terms of the Creative Commons Attribution License which permits any use, distribution, and reproduction in any medium, provided the original author(s) and the source are credited.

\section{References}

Chamberlain SC (2008) Zonneveld's study of cell layers and leaf variegation in Hosta cultivars: a summary for gardeners. The Hosta J 39-2:66-69

Chamberlain SC, Pollock WI, Zonneveld BJM (2011) Ploidy and pollen viability in Hosta cultivars: Zonneveld's Data Sets. The Hosta J 42-1:71-78

De Schepper S, Leus L, Mertens M, Debergh O, Van Bockstaele E, de Loose M (2001) Somatic polyploidy and its consequences for flower coloration and flower morphology in Azalea. Plant Cell Rep 20:583-590

Doležel J, Bartos J, Voglmayer H, Greilhuber J (2003) Nuclear DNA content and genome size of trout and human. Cytometry 51a:127-128

Galbraith DW, Harkins KR, Maddox JM, Ayres NM, Sharma DP, Firoozabady E (1983) Rapid flow cytometric analysis of the cellcycle in intact plant-tissues. Science 220:1049-1051

Kaneko K (1968) Cytological studies on some species of Hosta III. Karyotypes of $H$. clausa, $H$. clausa var. normalis and $H$. ventricosa. Bot Mag (Tokyo) 81:396-403

Lineberger RD (2000) Origin, development and propagation of chimeras. http://aggie-horticulture.tamu.edu/tisscult/Chimeras/ chimeralec/chimeras.html

Marcotrigiano M (1997) Chimeras and variegation: patterns of deceit. Hort Sci 32:773-784

Marcotrigiano M (2001) Genetic mosaics and leaf development. Int J Plant Sci 162:513-525

Phillips RL, Kaeppler SM, Olhoft P (1994) Genetic instability of plant tissue cultures: breakdown of normal controls. Proc Natl Acad Sci. USA 91:5222-5226

Roux N, Toloza A, Radecki A, Zapata-Arias FJ (2003) Rapid detection of aneuploidy in Musa using flow cytometry. Plant Cell Rep 21:483-490

Satina S, Blakeslee AF, Avery AG (1940) Demonstration of the three germ layers in the shoot apex of Datura by means of induced polyploidy in periclinal chimeras. Am J Bot 27:895-905

Stewart RN, Dermen H (1979) Ontogeny in monocotyledons as revealed by studies of the developmental anatomy of periclinal chloroplast chimeras. Am J Bot 66:47-58

Suda J, Krahulcova A, Travnicek P, Krahulec F (2006) Ploidy versus DNA ploidy level: an appeal for consistent terminology. Taxon 55:447-450

Tiersch TR, Chandle RW, Wachtel SSM, Ellias S (1989) Reference standards for flow cytometry and application in comparative studies of nuclear DNA content. Cytometry 10:706-710

Zonneveld BJM (2007) Nuclear DNA content of ploidy chimeras of H. Tratt. (Hostaceae) demonstrate three apical layers in all organs, but not in the adventitious root. Plant Syst Evol 269:29-38

Zonneveld BJM, Pollock WI (2012) Flow cytometric analysis of somaclonal variation in lineages of Hosta sports detects polyploidy and aneuploidy chimeras. Plant Biol (in press)

Zonneveld BJM, Van Iren F (2000) Flow cytometric analysis of DNA content in Hosta reveals ploidy chimeras. Euphytica 111:105-110

Zonneveld BJM, Van Iren F (2001) Genome size and pollen viability as taxonomic criteria: application to the genus Hosta. Plant Biol 3:176-185

Zonneveld BJM, Pollock WI, Mortko RA, Chamberlain SC (2009) $H$. 'Stitch in Time': a multiple mystery. The Hosta J 40-1:62-68 